\title{
Öğretmen Adaylarının Ders Esnasında Siber Aylaklık Yapma Nedenlerinin İncelenmesi ${ }^{1}$
}

\author{
DOI: 10.26466/opus.933566
}

\author{
* \\ Yusuf Tarık Tatlı*- Fatma Sadık ${ }^{* *}$ \\ * Öğretmen, MEB, Mersin/Türkiye \\ E-Posta: ytariktatli@gmail.com \\ ORCID: $\underline{0000-0002-6115-878 X}$ \\ ** Doç.Dr., Çukurova Üniversitesi, Adana/Türkiye \\ E-Posta: fatmasdk@gmail.com \\ ORCID: $\underline{0000-0002-6565-5679}$
}

Öz

Öğretmen adaylarının ders esnasında siber aylaklık yapma nedenlerini inceleyen bu araştırma tarama modelinde betimsel bir çalışmadır. Araştırmaya bir devlet üniversitesinin eğitim fakültesinin farklı bölümlerine devam eden toplam 918 öğretmen adayı gönüllü olarak katılmıştır. Araştırma verileri 20172018 öğretim yılı güz döneminde, Genç ve Tozkoparan (2017) tarafindan geliştirilen Siber Aylaklık Nedenleri Ölçeği ve araştırmacılar tarafindan hazırlanan Kişisel Bilgi Formu ile toplanmıştır. Veri analizinde betimsel istatistiklerin yan stra Mann Whitney- $U$ ve Kruskal Wallis $H$ testleri kullanılmıştır. Araştırma sonucunda öğretmen adaylarının daha çok güdülenme ve yürütücü kaynaklı nedenlerle siber aylaklık yaptıkları belirlenmiştir. Öğretmen adaylarının siber aylaklık yapma nedenleri yaşlarına ve sınıf düzeylerine göre anlamlı bir farklılık göstermemiş ancak farklı bölümlere devam eden öğretmen adaylarının siber aylaklık yapma nedenleri "Güdülenme" ve "Derse ilişkin tutum" boyutunda anlamlı bir şekilde farklılaşmıştır. Sınıf Ĕ̆itimi ve Resim-iş Eğitimi Bölümü öğrencilerinin güdülenme konusunda daha az sorun yaşadığı, Simıf Eğitimi, Okul Öncesi Ĕ̆itim ve Resim-iş Ĕ̆itimi bölümü ögrencilerinin derse yönelik tutumlarının nispeten daha olumlu olduğu saptanmıştır. Sonuçlar alan bilgisi derslerinde erkek, seçmeli ve meslek derslerinde ise kadın öğretmen adaylarının daha çok siber aylaklık yaptı̆̆ını göstermiştir. Seçmeli derslerde siber aylaklık yapma oranı Rehberlik ve Psikolojik Danışma ve Sınıf Eğitimi; alan bilgisi ve meslek derslerinde Resim Eğitimi; genel kültür derslerinde Fen Bilimleri Ĕ̆gitimi bölümlerine devam eden öğretmen adaylarında daha yüksek olmuştur.

Anahtar Kelimeler: Siber Aylaklık, Siber Aylaklık Nedenleri, Öğretmen Adaylarl, Cep Telefonu.

\footnotetext{
${ }^{1}$ Bu çalışma Yusuf Tarık Tatı’’nın Doç. Dr. Fatma Sadık yönetiminde gerçekleştirdiği “Öğretmen adaylarının siber aylaklık davranışları ve nedenlerinin incelenmesi” başlıklı yüksek lisans tezinden üretilmiştir.
} 


\title{
Investigating the Reasons of Pre-Service Teachers' Cyberloafing During the Lesson
}

*

\begin{abstract}
This is a descriptive survey model study aiming at investigating the reasons of pre-service teachers' cyberloafing during the lesson. A total of 918 pre-service teachers from different departments of a state university participated in the research study. The data was collected in the 2017-2018 fall period through the Reasons for Cyber-Loafing Scale developed by Genç and Tozkoparan (2017) and a Personal Information Form developed by the researchers of this study. Mann Whitney-U and Kruskal Wallis $H$ tests as well as descriptive statistics were used for the data analysis. The study reveals that motivation and course-coordinator based reasons lead pre-service teachers to cyber loafing. The reasons for cyper loafing showed no significant difference according to the age or study level of the participants, however a significant difference was found in terms of "motivation" and "attitude towards course" among the pre-service teachers enrolled different departments. It was found that students from Primary Education Teaching Department and Art-Craft Teaching Department reported less problems with motivation, and students from Primary Education Teaching Department, Preschool Teaching Department and ArtCrafts Teaching Education departments had more positive attitudes towards the lesson. The results showed that male pre-service teachers performed more cyber loafing in elective courses while female preservice teachers performed cyber loafing in elective and vocational courses more. The rate of cyber loafing in elective courses were found higher among the participants from Guidance and Psychological Counseling and Primary Education Teaching Departments; that in vocational and subject matter knowledge courses was found higher in Arts Teaching while it was found higher among pre-service teachers Science Education departments in general culture courses.
\end{abstract}

Key Words: Cyberloafing, the Reasons of Cyber Loafing, Pre-Service Teachers, Smart Phones. 


\section{Giriş}

Teknolojinin yaygınlaşması, internetin hız ve erişilebilirlik anlamında oldukça iyi düzeylere gelmesi günlük hayatımızı oldukça kolaylaştırmaktadır. İnternet iş ortamlarında temel iş süreçlerinin yönetilmesini sağlamakta, eğitim alanında da ders materyallerine erişim, uzaktan eğitim, online sınavlar yapma vb. gibi farklı eğitsel amaçlarla kullanılmaktadır (Erişen ve Çeliköz, 2007). Ancak önce iş dünyasında (Lim, 2002) sonrasında eğitim ortamlarında bireylerin kurumun internet ağını kişisel amaçları doğrultusunda kullanmaya başlamalarıyla (Brubaker, 2006), 2000' li yıllardan itibaren toplumlar siber aylaklık/ sanal kaytarma (Cyberloafing) olarak adlandırılan yeni bir davranış biçimiyle karşı karşıya kalmıştır. Siber aylaklık genel olarak bilişim sistemlerinin kurumun amaçları dışında kullanılması olarak ifade edilmekte (Guthrie and Gray, 1996, s.23); kişisel e-posta alışverişi, internette gezinme, online alış-veriş yapma, facebook, twitter, blog sayfaları vb. sosyal ağlara girme, haber okuma ve spor sitelerine girme, mesaj alma-gönderme, eğlence ve oyun sitelerine girme vb. davranışları örnek gösterilmektedir (Blau, Yang and Wark-Cook, 2006).

Anandrajan, Devine ve Simmers' e (2004) göre; zarar verici veya bozucu siber aylaklık (Disruptive Cyberloafing), yaratıcı ve boş zamanları doldurucu siber aylaklık (Recreational Cyberloafing ) ve öğretici siber aylaklık (Personal Learning Cyberloafing) olmak üzere üç tür siber aylaklık vardır. Zarar verici ve bozucu siber aylaklık davranışlarına yetişkin sitelerine girme ve online oyunlar oynama; yaratıcı ve boş zamanları doldurucu siber aylaklığa online alışveriş yapma ve amaçsız olarak internette dolaşma örnek verilmektedir. Öğretici siber aylaklık ise kişisel gruplara üye olma, tartışma gruplarına katılma ve internet üzerinde bilgi toplama gibi etkinlikler içermektedir (Akt. Özkalp, Aydın ve Tekeli, 2012, s.24 ). Siber aylaklığ1 ciddi ve minör düzey olarak sinıflayan Blanchard ve Henle' ye (2008) göre ciddi düzey siber aylaklık; online kumar sayfalarında gezinme, yetişkin içerikli web sayfalarını ziyaret etme, illegal müzik indirme, blog sayfalarında gezinme, çevrimiçi sohbet odalarında zaman geçirme gibi etkinlikleri içermektedir. Minör düzeyde siber aylaklık davranışı ise mail alma-gönderme, haber ve finans 
sayfalarında gezinme ve çevrimiçi alışveriş yapma davranışlarından oluşmaktadır. İnce ve Gül' ün (2011) siber aylaklık sinıflaması ise;

Kişi veya kuruluş açısından zararlı olup olmadı̆̆ııa göre: Zararlı ve zararsız siber aylaklık

Etki ve sonuçlarına göre: Küçük ve ciddi siber aylaklık

Etik olma durumuna göre: Ahlaki ve ahlaki olmayan siber aylaklık

Yasaya uygunluk durumuna göre: Yasal ve yasadışı siber aylaklık

Harcanan zamana göre: Kısa süreli ve uzun süreli siber aylaklık

Yönetim politikalarına göre: Mücadele gerektiren siber aylaklık ve tolere edilebilir siber aylaklık şeklindedir.

Gelişen teknolojiyle birlikte siber aylaklık davranışlarına yeni boyutlar ve türler eklenmeye devam etmektedir (Candan ve İnce, 2016). Siber aylaklığın iş dünyasındaki sonuçları çoğunlukla kaynakların ekonomik kullanılmaması, iş veriminin azalması ve zaman kaybı olarak ifade edilmektedir (Andreassen, Torsheim and Pallesen, 2014; Koay, Soh and Chew, 2017). Bu nedenle gerek kamu ve gerekse özel çalışma alanlarında çalışanları siber aylaklığa yönelten iş yeri (ortam, iş yükü, çalışanlar) ve bireyle ilgili özellikler (psikolojik ihtiyaçlar, alışkanlıklar, bilgisayar ve internet kullanma becerileri) sık sık araştırmalara konu olmaktadır (Ahmad and Omar, 2017; Al-Shuaibi, Shamsudin and Subramaniam, 2013; Andreassen vd. 2014; Holguin, 2016; Huma, Hussain, Thurasamy and Malik, 2017; Koay, Soh and Chew, 2017). İlgili literatür incelendiğinde ülkemizde de son 10 yıldır özellikle emniyet, sağlık ve turizm sektörlerinde çalışanların siber aylaklık davranışlarının örgütsel adalet, örgütsel vatandaşlık, örgütsel bağlllık, psikolojik sözleşme algısı, iş stresi ve işe adanmışlık açısından inceleyen çalışmaların arttığı görülmektedir (Candan ve İnce, 2016; Demir ve Seferoğlu, 2016; Kaplan ve Çetinkaya, 2014; Kaplan ve Öğüt, 2012; Keklik, Kılıç, Yıldız ve Yıldız, 2015; Kutanis, Karakiraz ve Aras, 2014; Serttaş ve Şimşek, 2017; Ulukapı, Çelik ve Yılmaz, 2014; Yıldız, Yıldız ve İyigün, 2016; Yıldız, Yıldız ve Ateş, 2015; Yıldız ve Yıldız, 2015). Çalışmaya teşvik eden görev dağılımı yapma, çalışanlara aşırı iş yüklemeden kaçınma, oyun ve online alışveriş sayfalarının engellenmesi, kınama, uyarı vb. cezaların uygulanması, motivasyonu arttıran düzenlemeler yapma vb. genel olarak iş ortamında siber aylaklığı önleme ve azaltmaya yönelik öneriler arasında yer almaktadır (Andreassen vd. 2014; Koay vd. 2017). 
Konuyla ilgili eğitim alanında yapılan çalışmalar ise iş dünyasına göre henüz sınırlı sayıdadır. Ulaşılabilen çalışmalar incelendiğinde de çoğunlukla bilgisayar ve iletişim teknolojilerinin kullanıldığı bölüm veya derslere devam eden öğrencilerle gerçekleştirildiği görülmüştür (ChinHooi Soh, Koay and Lim, 2018; Ergün ve Altun, 2012; Hayıt ve Dönmez, 2016, Giles, 2015; Kalayc1, 2010; Knight, 2017; Kurt, 2011; Özcan, Gökçearslan ve Yüksel, 2017; Sarhangpour, Baezzat and Akbari, 2018; Soh ve Yeik, 2018; Wu, Mei and Ugrin, 2018; Yaşar, 2013). Odabaşı' na (2004) göre derslerin içeriği ve öğretim şeklindeki değişiklikler üniversitelerin yüksek hızda internet ağı ve teknolojik cihazlarla donatılmasıyla başladığı için konuyla ilgili çalışmaların üniversitelerde yoğunlaşması son derece doğaldır. Ancak günümüzde hızlı internet bağlantısına sahip tabletler ve cep telefonları gibi taşınabilir teknolojilerin yaygınlaşmasıyla insanlar artık her zaman her yerde internete erişebilir duruma gelmişlerdir (Baert et al. 2020; Knight, 2017). Birçok araştırma insanların günlük internet kullanım sürelerinin arttığını (Karaoğlan Yılmaz, Yılmaz, Öztürk, Sezer ve Karademir, 2015; Altay ve Özerbaş, 2020); mobil cihazların daha çok sosyal ağlara erişmek, eğlenmek, internette gezinmek ve video izlemek amacıyla kullanıldığını göstermektedir (Gezgin ve Çakır, 2016; Gezgin, Çakır ve Yıldırım, 2018). Tindell ve Bohlander'in (2012) üniversite öğrencileriyle yaptıkları çalışmada öğrencilerin \% 95'nin sınıfa cep telefonu getirdiği, \% 92'sinin ders esnasında, \% 10'unun sınav esnasında dahi mesajlaştığı saptanmıştır. Benzer bir çok çalışma ders esnasında internette gezinme, e-posta gönderme, video izleme, müzik dinleme ve oyun oynama etkinliklerinin öğrenciler arasında giderek yaygınlaştığını göstermektedir (Akgün, 2020; Altay ve Özerbaş, 2020; Arabac1, 2017; Cha and Seo, 2018; Çınar ve Cinisli, 2018; Çok ve Kutlu, 2018; Ergün ve Altun, 2012; Gökdaş, Torun ve Bağrıaçık, 2014; Hayıt ve Dönmez, 2016; Seçkin ve Kerse, 2017; Solmaz, Tekin, Herzem ve Demir, 2013; Twum, Yarkwah, ve Nkrumah,2021).Öğrencilerin sınıf ortamında sergiledikleri siber aylaklık etkinlikleri dikkate alındığında tüm örgün eğitim kademelerinde mevcut durumun ve nedenlerinin çok daha iyi anlaşılması gerektiği söylenebilir. Çünkü siber aylaklık sınıfta öğrenim için ayrılan sınırlı zamanı, öğrencilerin öğrenmelerini, öğretim elemanının öğretim ve yönetim davranışlarını olumsuz etkilemekte; derse yönelik dikkat, motivasyon, ilgi ve isteği azaltarak, çalışmada verimlilik ve akademik başarıda düşüşe 
neden olmaktadır (Bağrıaçık Yılmaz, 2017; Heflin, Shewmaker and Nguyen, 2017; Kalayc1, 2010; Kurt 2011; Li, Lepp and Barkley, 2015; Soh and Yeik, 2018; Şenel vd. 2019; Taneja, Fiore and Fischer, 2015; Wu, Mei and Ugrin, 2018; Yaşar 2013; Yıldırım, 2016).

İlgili literatürde siber aylaklığın nedenleriyle ilgili farklı görüşlere rastlanmaktadır. Okul laboratuvarlarında internet ağ1 ve bilgisayarların varlığı; öğrencilerin cep telefonlarını okula getirmeleri, internetten yararlanma maliyetinin azalması, gençlerin yeni teknolojilere hemen adapte olması, bilgisayar, tablet ve internet kullanımının yaygınlaşması en sık dile getirilen nedenler arasındadır (Seçkin ve Kerse, 2017; Akbulut, Dursun, Dönmez ve Şahin, 2016). Mayfield' e (2010) göre bu artış sosyal medyanın katılımcıları cesaretlendirmesi, geribildirime ve katılımcılara açık olması, kişilerin sevdikleri fotoğraf, değerler, konular, favorileri olan program ve şovları vb. paylaşma ve ilgili oldukları herhangi bir konuda link bulmalarına olanak tanımasından kaynaklanmaktadır (Akt. Vural ve Bati, 2010, s.3351-3352). Ünver ve Koç (2017, s.119) ise internetin sağladığ1 imkânlar, oluşturduğu kolaylıklar ve yaşattığı serbestlik duygusu ile insanı bir süre sonra kendisine bağımlı hale getirebilecek bir yapıya sahip olduğunu belirtmektedir. Nitekim Wu, Mei ve Ugrin (2018), Soh ve Yeik (2018) araştırmalarında öğrenci alışkanlıklarının siber aylaklık davranışlarını önemli ölçüde yordadığını saptamışlardır. Ancak ifade edilen bu faktörler daha çok teknolojideki gelişmelerle kişilerin cep telefonu ve internet kullanma alışkanlıklarıyla ilgilidir. Öğrencilerin derste siber aylaklık davranışlarını azaltmak veya önleyebilmek için onları sınıf ortamında/ders esnasında bu etkinlikleri yapmaya yönelten nedenlerin de anlaşılması gerekmektedir. Bu konuda ulaşılabilen sınırlı sayıda araştırma incelendiğinde siber aylaklığın kişinin (içsel), sınıf ortamının (dışsal) ve çalışmanın/iş, görev özellikleriyle birlikte ele alındığ1 görülmüştür (Bağriaçık Yılmaz, 2017; Ergün ve Altun, 2012; Galluch and Thatcher, 2007; Sarhangpour, Baezzat and Akbari, 2018; Şenel vd. 2019; Yıldırım, 2016). Örneğin Galluch ve Thatcher (2007) öğrencilerin ders esnasinda dersle ilgisi olmayan işler yapmaya niyet etmeleri ve birbirlerinden etkilenmelerini siber aylaklık nedenleri olarak belirlerken; Şenel vd. (2019) öğrencilerin öğrenmeye karşı isteksizliğini vurgulamışlardır. Bağrıaçık Yılmaz'ın (2017) çalışmasında öğrenciler sınıfta siber aylaklığa yönelten kişisel faktörleri; merak, ilgi, dikkat 
dağınıklığı, odaklanma sorunu ve alışkanlıklar olarak ifade etmişlerdir. Aynı çalışmada internet erişimi, bildirimler, reklamlar-web önerileri ve telefon sesi dişsal; yorulma, ara verme veya kafa dağıtma isteği ve çalışmanın uzun olması ise çalışmayla ilgili özellikler olarak vurgulanmıştır. Sarhangpour, Baezzat ve Akbari (2018) tarafından yapılan çalışmada da siber aylaklık davranışları ile psikolojik ihtiyaçlar arasındaki ilişkiye bakılmış ve " eğlence ihtiyacı" ile eğlenme yönündeki siber aylaklık davranışları arasında anlamlı bir doğrusal ilişki olduğu saptanmıştır.

$\mathrm{Bu}$ araştırmada ise öğrencileri sınıf ortamında siber aylaklık yapmaya yönelten nedenler; güdülenme, dersin yürütücüsü ve derse ilişkin tutum kapsamında ele alınmıştır. Güdülenme kaynaklı nedenler, öğrencilerin öğrenmeye ve ders etkinliklerine yönelmelerine ilişkin iç ve dış etkenleri; derse ilişkin tutum öğrencilerin dersi takip etme ve ders içinde kendilerine verilen görevleri yapmaya yönelik tutumlarını; yürütücü kaynaklı nedenler ise dersi veren öğretim elamanının dersteki tutumu, kullandığ yöntemleri ve öğrencilerle ilişkilerini vb. içermektedir (Genç ve Tozkoparan, 2017). Araştırmada öğretmen adaylarıyla çalışılma nedeni ise, günümüzde büyük bir hızla yaşanan gelişmelere ayak uydurmak için nitelikli eğitime ve nitelikli öğretmenlere olan ihtiyacın giderek artmasıdır (Caena, 2014; Jiang, Lin and Mariano, 2016). Öğretmenler eğitim sisteminin ana öğelerinden biri olup, sahip oldukları niteliklerle eğitimin diğer öğelerini etkileme, geliştirme, dönüştürme gücüne sahiptir (Adıgüzel, 2008). Eğitimde kalitenin yolu öğretmen niteliklerinin artırılmasından geçmekte, bu da öğretmenlerin hizmet öncesi eğitimlerinden atanmalarına, okuldaki performanslarından hizmet içi eğitimlerine kadar tüm unsurların titizlikle ele alınmasını gerektirmektedir (Karaca, 2007). Bu açıdan öğretmen adaylarının hizmet öncesi eğitimleri sırasında performanslarını etkileyen unsurların incelenmesi büyük önem taşımaktadır. Sınıf ortamında öğrenme-öğretme sürecinin etkililiği öğrencilerin derste aktif olmalarına bağlıdır. Her ne kadar öğretim elemanları öğrencilere öğrenme süreçlerinde yapmaları gereken davranışlar, beklentiler, sorumluluklar hakkında açılamalar yapsalar da öğrenme süreci bireyin kendi kontrolü altındadır. Bir diğer ifadeyle her öğrenci kendi öğrenmesinden birincil derecede sorumludur. $\mathrm{Bu}$ araştırma öğretmen adaylarını ders sırasında sorumluluklarını yerine 
getirmekten alıkoyan ve siber aylaklık yapmaya yönelten/iten unsurları belirleme ve siber aylaklık davranışların giderilmesine yönelik öneriler getirmeyi amaçlaması bakımından önemlidir. Elde edilen sonuçların gerek sınıf ortamında siber aylaklığı en aza indirgemeye yönelik alınabilecek önlemlere, gerekse öğretmen yetiştirme sürecinin niteliğine katkı sağlamaya yönelik tartışmalara ışık tutacağı düşünülmektedir.

Temel amacı öğretmen adaylarının ders esnasında siber aylaklık yapma nedenlerini incelemek olan bu araştırmada aşağıdaki sorulara yanit aranmıştır:

1. Öğretmen adaylarının ders sırasında/sınıf ortamında siber aylaklık yapma nedenleri nelerdir?

2. Öğretmen adaylarının siber aylaklık yapma nedenleri cinsiyet, yaş, bölüm ve sınıf düzeylerine göre anlamlı farklılık göstermekte midir?

3. Öğretmen adayları hangi derslerde siber aylaklık davranışlarına daha sık yönelmektedirler?

4. Öğretmen adaylarının siber aylaklık davranışlarına daha sık yöneldikleri derslerin cinsiyet, yaş, bölüm ve sinıf düzeylerine göre dağılımı nasıldır?

\section{Yöntem}

\section{Araştırmanın Modeli}

Araştırma tarama modelinde, betimsel bir çalışmadır Tarama modellerinin amacı var olan bir durumu tanımlamaktır. Herhangi bir şekilde değiştirme veya etkileme çabası gösterilmez. Araştırmacı olgulara müdahale etmez, olayların akışını değiştirmez. Önemli olan var olanı uygun bir şekilde gözleyip, olduğu gibi belirleyebilmektir (Karasar, 2012, s.77). Bu araştırmada öğretmen adaylarının siber aylaklık yapma nedenleri farklı değişkenler açısından betimlenmeye çalışılmıştır.

\section{Evren ve Örneklem}

Araştırma, bir devlet üniversitesinin eğitim fakültesinin farklı bölümlerine devam eden öğretmen adaylarıyla gerçekleştirilmiştir. 
Katılımcıların evreni temsil edecek şekilde araştırmada yer almasını sağlamak için her bölümün tüm sınıf düzeylerinden (1-2-3-4. sinıf) birer grup random yöntemiyle örnekleme dâhil edilmiştir. Veri toplama araçları belirlenen gruplarda derse giren öğretim elemanları tarafından uygulama yapılan gün/günlerde sinıfta olan bütün öğrencilere ulaştırılmıştır. Araştırmaya toplam 918 öğretmen adayı gönüllü olarak katılmıştır. Katılımcıların \% 12.2' si Sınıf Eğitimi, \%18.5' i Okul Öncesi Eğitimi, \%12.3' ü Fen Bilimleri Eğitimi, \%14.7' si Sosyal Bilimler Eğitimi, \%14.8' i Türkçe Eğitimi, \%8.6' sı Resim-iş Eğitimi ve \% 18.8' i Rehberlik ve Psikolojik Danışma bölümlerine devam etmektedirler. Öğrencilerin \%70.8' i kadın, \%29.2' si erkek olup; \%48.6' si 21-23, \%42.9' u 18-20, \%8.5'i 24-27 yaş aralığındadır. Sınıf düzeylerine göre katılımcıların \%25.2' si birinci sınıf, \%25.1' i ikinci sınıf, \% 30.9' u üçüncü sınıf ve \% 18.8' i dördüncü sınıfta öğrencidir.

\section{Veri Toplama Araçları}

Araştırma verilerinin toplanmasında Genç ve Tozkoparan (2017) tarafından geliştirilen Siber Aylaklık Nedenleri Ölçeği (SANÖ) ve araştırmacılar tarafından hazırlanan Kişisel Bilgi Formu kullanılmıştır.

SANÖ; Güdülenme (4 madde), Yürütücü kaynaklı nedenler (4 madde) ve Derse ilişkin tutum ( 3 madde) olmak üzere üç alt boyut ve toplam 11 maddeden oluşmaktadır. Ölçeğin KMO değeri .83; Bartlett testi sonucu $\chi 2=581,899 ; \mathrm{sd}=55$ ' dir. Madde faktör yükleri .40-.82 arasında değişmektedir. "Güdülenme" faktörü toplam varyansın \%38.1'ini, "Güdülenme" ve "Yürütücü Kaynaklı Nedenler" faktörleri birlikte toplam varyansın \%51.1'ini, üç faktör birlikte toplam varyansın \%60.8' ini açıklamaktadır. Maksimum olasılık tekniği kullanılarak yapılan doğrulayıcı faktör analizi sonucunda uyum indeksleri CMIN/DF (X2 /sd)=3,70; GFI=.948; CFI=.919; AGFI=.916; NFI=.893; RMSEA=.075 ve SRMR=.0472 olarak bulunmuştur. Ölçeğin Cronbach's Alpha güvenirlik katsayıları "Güdülenme" faktörü için .75; "Yürütücü Kaynaklı Nedenler" faktörü için .64, "Derse İlişkin Tutum" faktörü için .69 ve ölçeğin geneli için .83'tür. Ölçekte yer alan maddeler "(1) Hiçbir zaman”, "(2) Nadiren”, (3) Ara sıra", “(4) Genellikle" ve "(5) Her zaman” şeklinde cevaplanmaktadır (Genç ve Tozkoparan, 2017). Ölçekte yer alan “ 
Laboratuvar ortamı sıkıcı geliyor" maddesi Genç ve Tozkoparan' dan (2017) alınan izinler doğrultusunda bu araştırmada "Sınıf ortamı sıkıcı geliyor" şeklinde değiştirilerek uygulanmıştır. Uygulama sonrasında öğretmen adaylarından elde edilen veriler üzerinde ölçeğin iç güvenirlik katsayıları tekrar hesaplanmış, Cronbach's Alpha güvenirlik katsayıları Güdülenme" faktörü için .82; "Yürütücü Kaynaklı Nedenler" faktörü için .54, “Derse İlişkin Tutum" faktörü için .71 ve ölçeğin geneli için .80 bulunmuştur.

Kişisel Bilgi Formu ise öğrencilerin demografik özellikleri hakkında dört (cinsiyet, yaş, bölüm ve sınıf düzeyi) ve öğrencilerin hangi derslerde cep telefonlarından internete girdiklerini belirlemeye yönelik bir kapalı uçlu soru olmak üzere toplam beş sorudan oluşmaktadır.

Araştırma verileri 2017-2018 öğretim yılı güz döneminde toplanmıştır. Veri toplama araçları araştırmanın yapıldığı devlet üniversitesinin rektörlügünden alınan izinler doğrultusunda araştırmaya katılmayı kabul eden bölümlerin örneklemde yer alan gruplarında/şubelerinde uygulanmıştır. Uygulama sürecinde öğretim aksatılmamış ve herhangi bir sorunla karşılaşılmamıştır.

\section{Veri Analizi}

İlk olarak öğretmen adaylarının SANEÖ' den elde ettikleri puanlar hesaplanmış, sonrasında bu puanlar üzerinde betimsel istatistikler (aritmetik ortalama ve standart sapma) yapılmıştır. Yorumlamada kolaylık sağlaması açısından elde edilen puanlar alt ölçeklerdeki madde sayısına bölünerek 1-5 arasında değerler elde edilmiştir. Bu değerler; $1.00-$ 1.80'e kadar "Hiçbir zaman", 1.81-2.60'a kadar "Nadiren"; 2.61-3.40'a kadar "Ara sira"; 3.41-4.20'ye kadar "Genellikle" ve 4.21-5.00'ye kadar "Her zaman" aralıklarına göre değerlendirilerek yorumlanmıştır. Daha sonra SANÖ puanlarının normallik sayıltısını karşılayıp karşılamadığı incelenmiştir. Tablo 1, SANÖ' en elde edilen verilerin normallik testi analiz sonuçlarını göstermektedir. 
Tablo 1. SANÖ Puanlarına Yönelik Normallik Testi Analizleri

\begin{tabular}{lllllll}
\hline & \multicolumn{5}{l}{ Kolmogorov-Smirnov } & \multicolumn{5}{l}{ Shapiro-Wilk } \\
\cline { 2 - 7 } & Statistic & df & Sig. & Statistic & df & Sig. \\
\hline Güdülenme & .075 & 918 & .000 & .986 & 918 & .000 \\
Yürütücü kaynaklı nedenler & .096 & 918 & .000 & .980 & 918 & .000 \\
Derse ilişkin tutum & .153 & 918 & .000 & .949 & 918 & .000 \\
\hline
\end{tabular}

Tablo 1 incelendiğinde Kolmogorov-Smirnov ve Shapiro-Wilk testlerinin anlamllık düzeylerinin .05’ den küçük olduğu görülmektedir. Bu sonuç ölçümlerin normallik sayıltısını karşılamadığını göstermektedir (Büyüköztürk, 2006, s.42). Bu nedenle katılımcıların ölçek puanlarının karşılaştırılmasında Mann Whitney- $U$ testi ve Kruskal Wallis $H$ testi uygulanmış, gözlenen anlamlı farklılıkların hangi gruplar lehine olduğunu belirlemek için grupların ikili kombinasyonları üzerinde Mann Whitney U testleri tekrarlanmıştır. Tüm analizlerde anlamlılık düzeyi .05 kabul edilmiştir.

\section{Bulgular}

\section{Öğretmen Adaylarının Sınıf Ortamında Siber Aylaklık Yapma Nedenleriyle İlgili Bulgular}

Tablo 2 araştırmaya katılan öğretmen adaylarının SANÖ puanlara ait betimsel istatistikleri göstermektedir.

Tablo 2. SANÖ Puanlarına Ait Betimsel Istatistikler (N=918)

\begin{tabular}{lccl}
\hline Ölçek alt-boyutları & $\overline{\mathrm{X}}$ & $\mathrm{Ss}$ & Katılma düzeyi \\
\hline Güdülenme & 2.88 & .80 & Ara sıra \\
Yürütücü kaynaklı nedenler & 2.88 & .70 & Ara sıra \\
Derse ilişkin tutum & 2.27 & .81 & Nadiren \\
\hline
\end{tabular}

Tablo 2'de görüldüğü gibi öğretmen adaylarının SANÖ puanlarına ait aritmetik ortalamalar "Güdülenme" ve "Yürütücü kaynaklı nedenler" alt boyutlarında 2.88, "Derse ilişkin tutum" alt boyutunda ise 2.31' dir. Bu durum katılımcların siber aylaklık davranışlarında güdülenme ve yürütücü kaynaklı nedenlerin nispeten daha önemli bir rol oynadığını göstermektedir. 


\section{Öğretmen Adaylarının Sınıf Ortamında Siber Aylaklık Yapma Nedenlerinin Çeşitli Değişkenlere Göre İncelenmesiyle Elde Edilen Bulgular}

Katılımcıların eğitim ortamında siber aylaklık yapma nedenleri arasında cinsiyet, yaş, bölüm ve sinıf düzeylerine göre anlamlı farklılıklar olup olmadığını test etmek amacıyla yapılan istatistiksel analizlerin sonuçları aşağıda yer almaktadır.

Cinsiyet: Tablo 3, öğretmen adaylarının SANÖ puanlarının cinsiyete göre Mann Whitney- U testi sonuçlarını göstermektedir.

Tablo 3. SANÖ Puanlarının Cinsiyete Göre Mann Whitney- U Testi Sonuçları

\begin{tabular}{lllllll}
$\begin{array}{l}\text { Ölçek } \\
\text { alt- boyutları }\end{array}$ & Grup & $\mathbf{N}$ & $\begin{array}{l}\text { Sira } \\
\text { Ortalaması }\end{array}$ & $\begin{array}{l}\text { Sira } \\
\text { Toplamı }\end{array}$ & U & p \\
\hline Güdülenme & Erkek & 268 & 496.30 & 133009.00 & 77237.000 & $.007^{*}$ \\
& Kadın & 650 & 444.33 & 288812.00 & & .141 \\
\hline Yürütücü kaynaklı & Erkek & 268 & 479.43 & 128487.00 & 81759.000 & \\
nedenler & Kadın & 650 & 451.28 & 293334.00 & & $.000^{*}$ \\
\hline Derse ilişkin tutum & Erkek & 268 & 515.99 & 138285.50 & 71960.500 & \\
& Kadın & 650 & 436.21 & 283535.50 & & \\
\hline
\end{tabular}

Tablo 3 incelendiğinde ölçeğin “Güdülenme" ve “Derse ilişkin tutum” alt boyutlarında erkek öğretmen adaylarına ait puan ortalamaların anlamlı bir şekilde daha yüksek olduğu görülmektedir [U=77237.000, 71960.500, p $<.05]$.

Yaş: Öğretmen adaylarının SANÖ puanlarının yaşlarına göre Kruskal Wallis $\mathrm{H}$ testi sonuçları Tablo 4' de verilmiştir.

Tablo 4. SANÖ Puanlarının Yaşa Göre Kruskal Wallis H Testi Sonuçları

\begin{tabular}{lllllll}
$\begin{array}{l}\text { Ölçek } \\
\text { alt-boyutlanı }\end{array}$ & Grup & $\mathbf{N}$ & Sira Ortalaması & $\chi^{2}$ & Sd & p \\
\hline Güdülenme & 18-20 yaş (A) & 394 & 464.62 & 4.926 & 2 & .085 \\
& 21-23 yaş (B) & 446 & 466.06 & & & \\
& 24-27 yaş (C) & 78 & 396.10 & & & .760 \\
\hline \multirow{3}{*}{ Yürütücü kaynaklı } & 18-20 yaş (A) & 394 & 452.36 & .550 & 2 & \\
nedenler & 21-23 yaş (B) & 446 & 465.85 & & & .227 \\
\hline \multirow{2}{*}{ Derse ilişkin tutum } & 24-27 yaş (C) & 78 & 459.24 & & 2.966 & 2 \\
& 18-20 yaş (A) & 394 & 471.54 & & & \\
\hline
\end{tabular}


Tablo 4' de görüldüğü gibi öğretmen adaylarının eğitim ortamında siber aylaklık yapma nedenleri yaşlarına göre anlamlı bir farklılık göstermemektedir ( $p>.05)$.

Bölüm: Katılımcıların SAEÖ puanlarının devam ettikleri bölümlere göre Kruskal Wallis $\mathrm{H}$ testi sonuçları Tablo 5’ de yer almaktadır.

Tablo 5. SANÖ Puanlarının Bölümlere Göre Kruskal Wallis H Testi Sonuçları

\begin{tabular}{|c|c|c|c|c|c|c|c|}
\hline & Grup & $\mathbf{N}$ & Sira Ort. & $\chi^{2}$ & Sd & $\mathrm{p}$ & Anlamlı fark \\
\hline \multirow{7}{*}{ 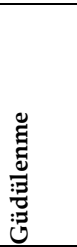 } & SE (1) & 112 & 397.17 & 14.322 & 6 & $.026^{*}$ & $1<2,4,5,7$ \\
\hline & OÖE (2) & 170 & 484.61 & & & & $6<2,5,7$ \\
\hline & FBE (3) & 113 & 458.54 & & & & \\
\hline & SBE (4) & 135 & 469.84 & & & & \\
\hline & TE (5) & 136 & 474.33 & & & & \\
\hline & RE (6) & 79 & 397.51 & & & & \\
\hline & RPD (7) & 173 & 484.38 & & & & \\
\hline \multirow{7}{*}{ 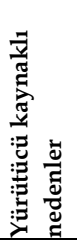 } & SE $\quad(1)$ & 112 & 446.07 & 6.574 & 6 & .362 & \\
\hline & OÖE (2) & 170 & 486.21 & & & & \\
\hline & FBE (3) & 113 & 460.24 & & & & \\
\hline & SBE & 135 & 480.62 & & & & \\
\hline & $\mathrm{TE}$ & 136 & 432.66 & & & & \\
\hline & $\mathrm{RE}$ & 79 & 416.07 & & & & \\
\hline & RPD (7) & 173 & 465.92 & & & & \\
\hline \multirow{7}{*}{ 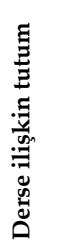 } & SE (1) & 112 & 395.51 & 14.861 & 6 & $.021^{*}$ & $1<3,4,5,7$ \\
\hline & OÖE (2) & 170 & 440.10 & & & & $2,6<5$ \\
\hline & FBE (3) & 113 & 479.89 & & & & \\
\hline & SBE (4) & 135 & 480.21 & & & & \\
\hline & TE & 136 & 503.48 & & & & \\
\hline & $\mathrm{RE}$ & 79 & 424.15 & & & & \\
\hline & RPD (7) & 173 & 472.08 & & & & \\
\hline
\end{tabular}

$\widehat{S E}=$ Sinı Ĕ̆itimi, OÖE= Okul Öncesi Ĕ̆itimi, FBE= Fen Bilimleri Ĕ̆itimi, SBE= Sosyal Bilimler Ĕğitimi, TE= Türkçe Ĕ̆itimi, RE= Resim-iş Ĕ̆itimi, RPD= Rehberlik ve Psikolojik Danışma Bölümü

Tablo 5 incelendiğinde öğretmen adaylarının ölçeğin "Güdülenme" ve "Derse ilişkin tutum" boyutlarına ait puanları arasında devam ettikleri bölümlere göre anlamlı farklar olduğu görülmektedir. Yapılan analizler "Güdülenme" boyutunda SE bölümüne devam eden öğrencilerin puanlarının diğer bölümlere devam eden; RE bölümündeki öğrencilerin puanlarının ise OOÖ, TE ve RPD bölümlerine devam eden öğrencilerin puanlarından daha düşük olduğunu göstermiştir $\left[\chi^{2}(6)=14.322, p<.026\right]$. "Derse ilişkin tutum" boyutunda da benzer sonuçlar elde edilmiş, SE bölümüne devam eden öğrencilerin puanları diğer bölümlere devam eden 
öğrencilerden; OOÖ ve RE bölümündeki öğrencilerin puanları ise TE bölümündeki öğrencilerden düşük olmuştur $\left[\chi^{2}(6)=14.861, \mathrm{p}<.021\right]$.

Sınıf Düzeyi: Tablo 6, katılımcıların SAEÖ puanlarının sınıf düzeylerine göre Kruskal Wallis $\mathrm{H}$ testi sonuçlarını göstermektedir.

Tablo 6. SANÖ Puanlarının Sınıf Düzeylerine Göre Kruskal Wallis H Testi Sonuçları

\begin{tabular}{|c|c|c|c|c|c|c|}
\hline $\begin{array}{l}\text { Ölçek } \\
\text { alt-boyutları }\end{array}$ & Grup & $\mathbf{N}$ & Sira Ortalaması & $\chi^{2}$ & Sd & $\mathbf{p}$ \\
\hline \multirow{4}{*}{ Güdülenme } & 1.sinif & 231 & 439.61 & 5.241 & 3 & .155 \\
\hline & 2.sinif & 230 & 453.04 & & & \\
\hline & 3.sinif & 284 & 488.43 & & & \\
\hline & 4.sinif & 173 & 447.16 & & & \\
\hline \multirow{4}{*}{ Yürütücü kaynaklı nedenler } & 1.sinif & 231 & 428.28 & 5.387 & 3 & .120 \\
\hline & 2.sinif & 230 & 452.68 & & & \\
\hline & 3.sinif & 284 & 478.22 & & & \\
\hline & 4.sinif & 173 & 479.52 & & & \\
\hline \multirow{4}{*}{ Derse ilişkin tutum } & 1.sinif & 231 & 448.47 & .864 & 3 & .864 \\
\hline & 2.sinif & 230 & 468.48 & & & \\
\hline & 3.sinif & 284 & 456.58 & & & \\
\hline & 4.sinif & 173 & 467.10 & & & \\
\hline
\end{tabular}

Tablo 6' da görüldüğü gibi öğretmen adaylarının eğitim ortamındaki siber aylaklık yapma nedenlerinde sınıf düzeylerine göre anlamlı bir fark bulunmamaktadir ( $\mathrm{p}>.05)$.

\section{Öğretmen Adaylarının Siber Aylaklığa Daha Sık Yöneldikleri Derslerle İlgili Bulgular}

Hangi derslerde daha çok siber aylaklık yaptıkları sorusuna cevap veren 858 öğretmen adayından elde edilen verilere ait betimsel istatistikler Tablo 7 ' de yer almaktadır. 
Tablo 7. Derslerle Ilgili Betimsel İstatistikler

\begin{tabular}{lll}
\hline Dersler & $\mathrm{f}$ & $\%$ \\
\hline Dersine göre değişiyor & 13 & 1.52 \\
Alan bilgisi dersleri & 183 & 21.32 \\
Genel kültür dersleri & 141 & 16.43 \\
Meslek bilgisi dersleri (formasyon) & 88 & 10.26 \\
Seçmeli dersler & 433 & 50.47 \\
Toplam & 858 & 100.0 \\
\hline
\end{tabular}

Tablo 7 incelendiğinde öğretmen adaylarının \%1.52' sinin bu soruya "dersine göre değişiyor" şeklinde genel bir cevap vermeyi tercih ettiği görülmektedir. Bununla birlikle katılımcıların yarısından fazlası (\%50.47) seçmeli derslerde cep telefonundan internete daha sik girdiklerini belirtmiştir. Bunu \%21.32 oranı ile alan bilgisi dersleri ve $\% 16.43$ oranı ile genel kültür dersleri izlemiştir. Meslek derslerinde cep telefonundan internete daha sık girdiklerini belirten öğretmen adaylarının oranı ise $10.26^{\prime}$ dir.

\section{Öğretmen Adaylarının Siber Aylaklığa Daha Sık Yöneldikleri Derslerin Çeşitli Değişkenlere Göre İncelenmesiyle Elde Edilen Bulgular}

Aşağıda öğretmen adaylarının siber aylaklık davranışlarına daha sık yöneldikleri derslerin cinsiyet, yaş, bölüm ve sınıf düzeylerine göre dağılımını gösteren betimsel istatistikler verilmiştir.

Cinsiyet: Tablo 8, öğretmen adaylarının $(\mathrm{N}=858)$ siber aylaklığa daha sık yöneldikleri derslerin cinsiyete göre dağılımını göstermektedir.

Tablo 8. Derslerin Cinsiyete Göre Dağılımı

\begin{tabular}{lllll}
\hline \multirow{2}{*}{ Dersler } & Erkek & \multicolumn{3}{c}{ Kadın } \\
\cline { 2 - 5 } Dersine göre değişiyor & $\mathbf{f}$ & $\mathbf{\%}$ & $\mathbf{f}$ & $\mathbf{\%}$ \\
Alan bilgisi dersleri & 7 & 2.7 & 6 & 1.0 \\
Genel kültür dersleri & 60 & 23.7 & 123 & 20.3 \\
Meslek bilgisi dersleri (pedagoji) & 42 & 16.7 & 99 & 16.3 \\
Seçmeli dersler & 23 & 9.11 & 65 & 10.7 \\
Toplam & 120 & 47.7 & 313 & 51.7 \\
\hline
\end{tabular}

Tablo 8 incelendiğinde genel kültür derslerinde erkek (\%16.7) ve kadın (\%16.3) öğretmen adayları arasında oransal olarak büyük bir fark 
olmadığı görülmektedir. Bununla birlikte alan bilgisi derslerinde erkek (\%23.7); seçmeli (\%51.7) ve meslek derslerinde ise (\%10.7) kadın öğretmen adaylarının oranı nispeten daha yüksek olmuştur.

Yaş: Öğretmen adaylarının siber aylaklığa daha sık yöneldikleri derslerin yaşlarına göre dağılımı Tablo 9' da yer almaktadır.

Tablo 9. Derslerin Yaşa Göre Dağılımı

\begin{tabular}{lllllll}
\hline \multirow{2}{*}{ Dersler } & $\mathbf{1 8 - 2 0}$ yaş & $\mathbf{2 1 - 2 3}$ yaş & \multicolumn{3}{c}{$\mathbf{2 4 - 2 7}$ yaş } \\
\cline { 2 - 7 } & $\mathbf{f}$ & $\mathbf{\%}$ & $\mathbf{f}$ & $\mathbf{\%}$ & $\mathbf{f}$ & $\mathbf{\%}$ \\
\hline Dersine göre değişiyor & 4 & 1.1 & 8 & 2.0 & 1 & 1.4 \\
Alan bilgisi dersleri & 82 & 22.2 & 84 & 20.1 & 17 & 23.6 \\
Genel kültür dersleri & 67 & 18.2 & 63 & 15.1 & 11 & 15.3 \\
Meslek bilgisi dersleri & 28 & 7.6 & 55 & 13.2 & 5 & 7.0 \\
Seçmeli dersler & 188 & 50.9 & 207 & 49.6 & 38 & 52.7 \\
Toplam & 369 & 100.0 & 417 & 100.0 & 72 & 100.0 \\
\hline
\end{tabular}

Tablo 9' da görüldüğü gibi seçmeli dersler (\%52.7) ve alan bilgisi derslerinde (\%23.6) 24-27 yaş; genel kültür derslerinde 18 -20 yaş (\%22.2), meslek derslerinde ise 21-23 yaş (\%13.2) dilimindeki öğretmen adaylarınınım oranı nispeten daha yüksektir.

Bölüm: Tablo 10, öğretmen adaylarının siber aylaklığa daha sık yöneldikleri derslerin devam ettikleri bölümlere göre dağılımını göstermektedir.

Tablo 10. Derslerin Bölümlere Göre Dă̆ılımı

\begin{tabular}{|c|c|c|c|c|c|c|c|c|c|c|c|c|}
\hline \multirow[t]{2}{*}{ Bölüm } & \multicolumn{2}{|c|}{$\begin{array}{l}\text { Dersine göre } \\
\text { değişiyor }\end{array}$} & \multicolumn{2}{|c|}{$\begin{array}{l}\text { Alan bilgisi } \\
\text { dersleri }\end{array}$} & \multicolumn{2}{|c|}{$\begin{array}{l}\text { Genel kültür } \\
\text { dersleri }\end{array}$} & \multicolumn{2}{|c|}{$\begin{array}{l}\text { Meslek } \\
\text { dersleri }\end{array}$} & \multicolumn{2}{|c|}{ Seçmeli dersle } & \multicolumn{2}{|c|}{ Toplam } \\
\hline & $\mathrm{f}$ & $\%$ & $\mathrm{f}$ & $\%$ & $\mathrm{f}$ & $\%$ & $\mathrm{f}$ & $\%$ & $f$ & $\%$ & $\mathrm{f}$ & $\%$ \\
\hline SE & - & - & 19 & 18.3 & 20 & 19.2 & 3 & 2.9 & 62 & 59.6 & 104 & 100.0 \\
\hline OOÖ & 2 & 1.2 & 31 & 19.6 & 24 & 15.0 & 17 & 10.8 & 85 & 53.4 & 159 & 100.0 \\
\hline FBE & 2 & 1.8 & 18 & 16.4 & 25 & 22.7 & 6 & 5.4 & 59 & 53.7 & 110 & 100.0 \\
\hline SBE & 4 & 3.5 & 33 & 28.2 & 17 & 14.5 & 14 & 12.0 & 49 & 41.8 & 117 & 100.0 \\
\hline TE & - & - & 36 & 28.6 & 23 & 18.2 & 9 & 7.2 & 58 & 46.0 & 126 & 100.0 \\
\hline RE & - & - & 31 & 40.0 & 11 & 14.4 & 16 & 20.8 & 19 & 24.8 & 77 & 100.0 \\
\hline RPD & 5 & 3.0 & 15 & 9.0 & 21 & 12.7 & 23 & 14.0 & 101 & 61.3 & 165 & 100.0 \\
\hline
\end{tabular}

SE= Sinıf Ĕ̆itimi, OÖE= Okul Öncesi Ĕ̆itimi, FBE= Fen Bilimleri Eğitimi, SBE= Sosyal Bilimler Ĕğitimi, TE= Türkçe Ĕ̆itimi, RE= Resim-iş Ĕ̆itimi, RPD= Rehberlik ve Psikolojik Danışma Bölümü 
Tablo 10 incelendiğinde seçmeli derslerde RPD (\%61.3) ve SE (\%59.6); meslek (\%40.0) ve alan bilgisi derslerinde RE (\%20.8); genel kültür derslerinde FB (\%22.7); alan bilgisi derslerinde ise Resim Eğitimi (\%40.0) bölümlerine devam eden öğretmen adaylarının siber aylaklığa yönelme oranının daha yüksek olduğu görülmektedir.

Sınıf Düzeyi: Tablo 11, öğretmen adaylarının siber aylaklığa daha sık yöneldikleri derslerin sınıf düzeylerine göre dağılımını göstermektedir.

Tablo 11. Derslerin Sınıf Düzeyine Göre Dağılımı

\begin{tabular}{|c|c|c|c|c|c|c|c|c|c|c|c|c|}
\hline \multirow[t]{2}{*}{ Sinıf } & \multicolumn{2}{|c|}{$\begin{array}{l}\text { Dersine göre } \\
\text { değişiyor }\end{array}$} & \multicolumn{2}{|c|}{$\begin{array}{l}\text { Alan bilgisi } \\
\text { dersleri }\end{array}$} & \multicolumn{2}{|c|}{$\begin{array}{l}\text { Genel kültür } \\
\text { dersleri }\end{array}$} & \multicolumn{4}{|c|}{$\begin{array}{l}\text { Meslek bilgisiSeçmeli } \\
\text { dersleri dersler }\end{array}$} & \multicolumn{2}{|c|}{ Toplam } \\
\hline & $\mathrm{f}$ & $\%$ & $f$ & $\%$ & $\mathrm{f}$ & $\%$ & $\mathrm{f}$ & $\%$ & f & $\%$ & $\mathrm{f}$ & $\%$ \\
\hline 1.sinif & 1 & .5 & 35 & 16.7 & 45 & 21.5 & 9 & 4.3 & 119 & 57.0 & 209 & 100.0 \\
\hline 2.sinif & 2 & 1.0 & 58 & 26.2 & 33 & 15.0 & 18 & 8.1 & 110 & 49.7 & 221 & 100.0 \\
\hline 3.sinif & 8 & 3.0 & 64 & 24.1 & 38 & 14.3 & 36 & 13.6 & 119 & 45.0 & 265 & 100.0 \\
\hline 4.sinif & 2 & 1.2 & 26 & 16.0 & 25 & 15.3 & 25 & 15.3 & 85 & 52.2 & 163 & 100.0 \\
\hline
\end{tabular}

Tablo 11 incelendiğinde alan bilgisi derslerinde ikinci sınıf (\%26.2); genel kültür (\%21.5) ve seçmeli derslerde birinci sınıf (\%57.0); meslek bilgisi derslerinde ise dördüncü sınıf öğrencilerinin siber aylaklığa yönelmeoranın nispeten daha yüksek olduğu görülmektedir (\%15.3).

\section{Tartışma, Sonuç ve Öneriler}

$\mathrm{Bu}$ araştırma sonucunda öğretmen adaylarının siber aylaklığa yönelmelerinde güdülenme ve yürütücü kaynaklı nedenlerin derse yönelik tutumlarından daha önemli bir rol oynadığı saptanmıştır. Güdülenmişlik (motivasyon) öğrenmeyi etkileyen bireyle ilgili önemli faktörlerden biridir. Yüksek güdülenmişlik öğrencinin derse ve konuya yönelik dikkatini, öğrenebileceğine ilişkin özgüvenini ve öğrenme çabasını artırırken (Bloom, 2012), düşük güdülenmişlik, öğrencilerin ders dışı şeylerle ilgilenmesine neden olabilmektedir (Wimolmas, 2013). Slavin' e göre (2013) öğrencinin öğrenme motivasyonu öğrenme ortamı, öğrenme materyali, kendi kişilik özellikleri, öğretmenin tutum ve davranışları gibi birçok faktörden etkilenmektedir. Bununla birlikte yapılan araştırmalar öğrencilerin motivasyonlarının ortaya çıkmasında veya azalmasında en kritik faktörün öğretmen davranışları olduğunu 
göstermektedir. Elde sonuçlara göre öğretmenlerin verimli ders işlememe, hazırlıksız derse girme (Ünal, 2013), isteksiz ve coşkudan uzak bir ses tonuyla konuşma (Yıldırım, Ünal ve Sürücü, 2015), öğrencilerle ilgilenmeme (Sürücü ve Ünal, 2018), öğrencilerin amaçlarını ve yöntem tercihlerini ihmal etme (Lamb, 2017), olumsuz yargılarda bulunma (Ünal ve Gürsel, 2015), öğrencilere sayg1 duymama (Toker ve Baturay, 2021) davranışları öğrencilerin motivasyonlarını olumsuz etkilemektedir. Dolayısıyla bu sonuçlar öğretim elemanlarının derslerde ağırlıklı olarak bilgi aktarmaya odaklandığını, öğrencileri derste aktif kılacak süreçler izlemediklerini veya onlarla sağlıklı bir şekilde iletişime geçemediklerini düşündürmektedir.

Elde edilen sonuçlara göre öğretmen adaylarının siber aylaklığa yönelme nedenlerinde yaş ve sinıf düzeylerine göre anlamlı bir farklılık olmamıştır. Bununla birlikte Sınıf Eğitimi ve Resim-iş Eğitimi Bölümü öğrencilerinin güdülenme konusunda daha az sorun yaşadığı, Sınıf Eğitimi, Okul Öncesi Eğitim ve Resim-iş Eğitimi bölümü öğrencilerinin de derse yönelik tutumlarının nispeten daha olumlu olduğu saptanmıştır. Yapılan araştırmalar öğrencilerin derse ilgilerini kaybettiklerinde odaklanma problemi yaşadıklarını ve siber aylaklık yapmaya yöneldiklerini göstermektedir. Örneğin Ergün ve Altun' un (2012) araştırmasında öğrenciler ders esnasında siber aylaklık yapma nedenlerini; dersi ve öğretmenini sevmeme, derste başarılı olamayacaklarını ve dersin kendilerine bir yarar getirmeyeceğini düşünme olarak ifade etmişlerdir. Yıldırım (2016) tarafından yapılan araştırmada konuların yoğun veya gereksiz detay içermesi, öğretmenin derste farklı öğretim yöntem ve tekniklerinden yararlanmaması siber aylaklık nedenleri olarak saptanmıştır. Varol ve Yıldırım (2018), Dursun, Dönmez ve Akbulut (2017), Soh ve Yeik (2018) ve Chin-Hooi Soh, Koay ve Lim'in (2018) araştırmalarında ise derse katılımın öğrencilerin davranış kontrolüne karşı tutumlarında ve siber aylaklık davranışlarına yönelmelerinde/yönelmemelerinde önemli bir rol oynadığı görülmüştür. Bu durumda Sınıf Eğitimi Bölümü programının farklı disiplinlerden beslenmesi, Resim-İş Eğitimi ve Okul Öncesi Eğitimi programında ise uygulamaya dönük derslerin daha fazla olmasının öğrencileri aktif kılarak sıkılmalarını engellediği ve siber aylaklık davranışlarını azalttığı söylenebilir. Flanigan ve Babchuk (2015) tarafından yapılan araştırmada 
öğrencilerin aktif oldukları derslerde can sıkıntısının ve siber aylaklık isteklerinin azaldığını; Twum, Yarkwah and Nkrumah' in çalışmasında (2021) derse yeterince katılmadıklarında siber aylaklığın tetiklendiğini belirtmeleri bu yorumu destekler niteliktedir.

Araştırmadan elde edilen bir diğer önemli sonuç, öğretmen adaylarının çoğunlukla seçmeli derslerde siber aylaklığa yönelmesidir. Seçmeli dersler eğitimin çeşitlenmesine, öğrencilerin farklı alanlarda yeteneklerini geliştirmelerine ve ilgi alanlarına yönelik daha fazla bilgi sahibi olmalarına olanak sağlayan derslerdir (Demir ve Ok, 1996). Ancak uygulamada gerek öğrencilerin gerekse dersi veren öğretim elemanlarının çeşitli sorunlar yaşadıklarını gösteren çalışmalar bulunmaktadır. Seçmeli ders sayısının azlığı, derslerin daha çok teorik olması, seçmeli derslerin öğrenciler tarafından not yükseltme aracı olarak görülmesi, ders saatlerinin çakışması, kontenjan sınırlaması, yabancı dil, spor, müzik, sanat alanlarında seçeneklerin az olması, ders saatlerinin azlığı dile getirilen sorunlardan bazılarıdır (Demir, 1996). Seçmeli derslerle ilgili yaşanan sorunlar Yükseköğretim Kurulu'nun 2018 yılında öğretmen yetiştirme lisans programlarında yaptığı geliştirme çalışmalarıyla önemli ölçüde giderilmeye çalışılmış, 25 programın tamamında seçmeli ders sayısı arttırılmıştır (YÖK, 2018). Yapılan araştırmalar bu düzenlemeyle birlikte seçmeli derslerin; alana dönük ve işlevsel olma, üniversiteler arası yaşanan seçmeli ders farklılıklarını azaltma, teknoloji entegrasyonu sağlama, öğrencilerin seçim yapma şanslarının artması, meslek bilgisi ve genel kültür seçmeli derslerinin bütün lisans programlarında ortak alınabilmesi yönlerinden çoğunlukla olumlu değerlendirildiğini göstermektedir. (Aykaç ve Stebler, 2019; Dağtekin ve Zorluoğlu, 2019; Tokcan ve Tangülü, 2019; Yurdakal, 2018; Ülger, 2019).

Bu durumda araştırmadan elde edilen sonuçların örneklemde yer alan öğretmen adaylarının bireysel farklılıklarından kaynaklandığı söylenebilir. Sonuçta her öğretmen adayının ilgi ve yönelimleri farklıdır. Tezcan ve Gümüş (2008), üniversite öğrencilerinin seçmeli ders seçiminde etkili olan faktörleri; öğrencilerin dersi veren öğretim elemanı hakkındaki görüşleri, dersin içerik olarak daha önce aldığı ve başarılı olduğu derslere yakın olması ve dersin işleniş yöntemi olarak belirlemiştir. Dolayısıyla bu sonuç seçmeli derslerle ilgili havuz çeşitlenmiş olsa da katılımcıların 
farklı nedenlerle ilgi ve ihtiyaçlarına uygun dersleri seçememiş olmalarından kaynaklanmış olabilir. İlgi duyulan bir ders seçilmiş olsa bile dersin içeriğini veya işleniş yöntemini mesleki ve bireysel ilgilerine cevap vermesi açısından yetersiz bulma da öğretmen adaylarının seçmeli derslerde daha fazla siber aylaklığa yönelmelerine neden olmuş olabilir.

Araştırma sonuçlarına göre seçmeli derslerde cep telefonundan internete girme oranının Rehberlik ve Psikolojik Danışma ve Sınıf Eğitimi; alan bilgisi ve meslek derslerinde Resim-iş Eğitimi; genel kültür derslerinde Fen Bilimleri Eğitimi bölümlerine devam eden öğretmen adaylarında daha yüksek olduğu görülmüştür. Alan bilgisi derslerinde siber ayaklık yapma oranı erkek öğretmen adaylarında, seçmeli dersler ve meslek derslerinde ise kadın öğretmen adaylarında daha yüksek olmuştur. "Güdülenme" ve "Derse ilişkin tutum" boyutlarında da erkek öğretmenlerin daha fazla sorun yaşadığı saptanmıştır. Bu sonuçlar erkek ve kadın öğretmen adaylarının devam ettikleri programlardan aldıkları doyum ve beklentilerindeki farklılıklarından kaynaklanmış olabileceği gibi mesleki ilgi alanlarıyla da (alan bilgisi, meslek bilgisi ve genel kültür) ilişkili olabilir. Örneğin Özgüngör (2010) çalışmasında üniversiteye gelme amacı diploma almak olan, akademik başarısı düşük öğrencilerin; Gündoğar vd. (2007) çalışmasında da okuduğu bölüme açıkta kalmamak amacıyla gelen öğrencilerin eğitim yaşantılarından aldıkları doyum ve öğretim elemanlarıyla ilişkilerine ait hoşnutluk düzeylerinin daha düşük olduğu saptanmıştır. Benzer şekilde birçok araştırma kadın öğretmen adaylarının mesleki ilgi ve tutumlarının erkeklerden daha olumlu olduğunu göstermektedir (Akdağ, 2014; Gökçe ve Sezer, 2012; Ömür ve Nartgün, 2013; Şahan ve Söğ, 2017; Şahin ve Şahin, 2017).

Cep telefonundan internete girme oranının alan bilgisi derslerinde dördüncü sınıf öğrencileri, yaş değişkeni açısından da 24-27 yaş dilimindeki öğretmen adaylarında nispeten daha yüksek olması ise öğrencilerin üst sınıflara doğru meslek ve alanlarıyla ilgili temel bilgilere sahip olduklarını düşünmelerinden kaynaklanmış olabilir. Arabacı (2017) ve Yaşar' ın (2013) araştırmalarında dördüncü sınıf öğrencilerinin diğer sinıf düzeylerindeki öğrencilere göre daha fazla siber aylaklık yaptığının saptanması; Yıldırım' in (2016) çalışmasında da öğrencilerin siber aylaklığa yönelme nedenlerini konuyu bilme ve konuyu ders 
kitaplarından da öğrenebileceklerini düşünme olarak belirtmeleri bu görüşü destekler niteliktedir.

Sonuç olarak bu araştırmada öğretmen adaylarının daha çok güdülenme ve yürütücü kaynaklı nedenlerle siber aylaklık yaptığı saptanmış, katılımcların siber aylaklık yapma nedenlerinde yaşlarına ve sınıf düzeylerine göre anlamlı bir farklılık olmamıştır. Öğretmen adaylarının daha çok seçmeli derslerde siber aylaklık yaptığı, cep telefonundan internete girme oranının alan bilgisi derslerinde ikinci sınıf; genel kültür ve seçmeli derslerde birinci sınıf; meslek bilgisi derslerinde ise dördüncü sınıf öğrencilerinde nispeten daha yüksek olduğu görülmüştür. Cinsiyet ve devam edilen bölüm öğretmen adaylarının siber aylaklık yapma nedenlerinde anlamlı farklılık yaratmış, seçmeli derslerde cep telefonundan internete girme oranının rehberlik ve psikolojik danışma ve sınıf eğitimi; alan bilgisi ve meslek derslerinde resim eğitimi; genel kültür derslerinde fen bilimleri eğitimi bölümlerine devam eden öğretmen adaylarında daha yüksek olduğu belirlenmiştir. Bu doğrultuda;

- Öğretimden sorumlu olan öğretim elemanlarının derslerde güdüleyici etkinliklere daha fazla yer vermeleri,

- Öğrenme-öğretme sürecinde öğrencileri aktif kılan öğretim yöntemleri kullanmaya ve çok yönlü iletişim kurmaya özen göstermeleri,

- Özellikle son sınıfta mikro öğretim uygulamalarına, öğretmen adaylarının staj uygulamalarıyla ilgili düşüncelerini ve deneyimlerini paylaşacakları tartışmalara, öğretim tasarımı yapma, materyal geliştirme gibi uygulamalı çalışmalara ağırlık verilmesi,

- Sinıf ortamında cep telefonu kullanımıyla ilgili sinıf kurallarının gözden geçirilmesi,

- Eğitim fakültelerinin alan içi ve alan dışı seçmeli derslerle ilgili havuza öğrencilerin bireysel farklılıklarına hitap edecek zenginlikte dersler eklemesi,

- Eğitim fakültelerindeki tüm bölümlerin öğretim programlarının geliştirilmesi gereken yönlerini tespit edilerek, gerekli önlemleri almaları önerilebilir.

$\mathrm{Bu}$ araştırmadan elde edilen sonuçlar bir devlet üniversitesinin eğitim fakültesindeki farklı bölümlere devam eden öğretmen adaylarıyla 
sınırlıdır. Bu konuda genellemelere ulaşabilmek için farklı üniversitelere devam eden öğrencilerle benzer çalışmalar yapılabilir. Öğretmen adaylarının siber aylaklık nedenleri arasında bu araştırmada kullanılan veri toplama aracında yer almayan özellikler de olabilir. Öğretmen adaylarını ders sırasında siber aylaklığa yönelten diğer durumların ve ders sirasinda cep telefonuyla internete girmenin onlara ne gibi olumlu ve olumsuz etkilerinin olduğunu belirlemek amaciyla öğrencilerle görüşmeye dayalı çalışmalar yapılabilir. Farklı derslerdeki öğrenmeöğretme süreçleri ve öğretim elemanlarının davranışlarının öğrenci davranışlarını nasıl etkilediği gözlem yoluyla incelenerek, öğretim elemanlarının bu yöndeki farkındalıkları arttırılabilir. Öğrencilerin eğitim ortamında siber aylaklık yapma nedenleriyle ilgili öğretim elemanlarının da görüşlerini alan karşılaştırmalı çalışmalar yapılabilir. 
EXTENDED ABSTRACT

\title{
Investigating the Reasons of Pre-Service Teachers' Cyberloafing During the Lesson
}

\author{
Yusuf Tarık Tatlı- Fatma Sadık \\ MONE-Çukurova University
}

\section{Introduction}

Since the 2000s, all societies have been facing a new behavior called cyberloafing. Cyberloafing is generally defined as the use of information systems for non-work-related purposes (Guthrie and Gray, 1996, p.23) such as surfing the Internet, online shopping, entering social networks namely facebook, twitter, blogs etc., as well as entering entertainment and gaming sites. Nowadays, thanks to portable technologies such as tablets and mobile phones with high-speed internet connection, people are able to access the internet anytime, anywhere and behaviors such as surfing the internet, watching videos, listening to music, or playing games during the lesson have become increasingly common among students at school (Akgün, 2020; Cha and Seo, 2018; Çınar and Cinisli, 2018; Tindell and Bohlander, 2012; Twum, Yarkwah and Nkrumah, 2021). The fact that cyberloafing causes a decrease in productivity and academic achievement by reducing attention, motivation, interest and desire is seen as the impact of cyberloafing on the learning-teaching process (Heflin, Shewmaker and Nguyen, 2017; Li, Lepp and Barkley, 2015; Soh and Yeik, 2018; Wu, Mei and Ugrin, 2018). In the related literature, the existence of internet networks and computers in school laboratories; coming to school with mobile phones, decreasing costs of using the internet, and the rapid adaptation of young people to new technologies are among the most frequently reported causes for cyberloafing (Seçkin \& Kerse, 2017; Akbulut, Dursun, Dönmez, \& Şahin, 2016). However, these factors are mostly related to the advances in technology and people's habits of using their mobile phones and the internet. It is necessary to understand the reasons why students tend to engage in such behavior during the lesson in order to discourage or prevent cyberloafing behavior of students at 
schools. The rationale of completing this research with pre-service teachers is that the need for qualified education and qualified teachers is currently increasing to keep up with current developments and changes (Caena, 2014; Jiang, Lin and Mariano, 2016). In this regard, it is significantly important to examine the factors affecting the performance of teacher candidates during their pre-service training.

\section{Method}

\section{Research Design}

This research, examining the reasons why pre-service teachers engage in cyberloafing during the lesson and in which courses they engage more in cyberloafing according to gender, age, department and class levels, is a descriptive survey model.

\section{Participants}

The research was carried out with 918 pre-service teachers enrolled at different departments at the education faculty of a state university. To ensure that the participants taking part in this research equally represent the population, a group randomly chosen from all years (1-2-3-4) of each department was included in the sample.

\section{Data Collection Tools}

The Reasons of Cyberloafing Scale developed by Genç and Tozkoparan (2017) and the Personal Information Form prepared by the researchers were used to collect the data of the study. The scale consists of three subscales namely "motivation", "attitude towards the lesson" and "instructor-induced" reasons and a total of 11 items. The answers can be given in the form of a 5-point Likert type. The Personal Information Form, on the other hand, consists of a total of five questions about the demographic characteristics of the students. The research data were collected in the fall semester of the academic year 2017-2018, and participation was voluntary. 


\section{Data Analysis}

In addition to descriptive statistics, the Mann Whitney-U and the Kruskal Wallis $\mathrm{H}$ tests were used for data analysis.

\section{Results, Discussion, and Recommendations}

At the end of the research, it was determined that pre-service teachers were mostly engaged in cyberloafing activities due to "motivation and "instructor-induced reasons". Although the students' motivation to learn is affected by many factors, the most critical factor is the teacher. Studies have shown that teachers who are unprepared for the lesson, speak with an unwilling tone, do not take care of students, do not activated them in the lesson, and make negative judgments about students' performances, negatively affect student motivation (Lamb, 2017; Toker \& Baturay, 2021). This situation makes us think that faculty of education instructors also just focus on transferring information during the lessons, that they do not use techniques to activate students in the lesson or that they cannot communicate well with them. The reasons for pre-service teachers' cyberloafing did not show significant difference according to their age or grade level. However, it was determined that the students of the Department of Primary Education and Art Education had less problems with motivation while the attitude of students at the Department of Primary Education, Pre-School Education and Art Education were more positive about the lectures. This may be due to the fact that the Department of Primary Education curriculum consists of different disciplines and that the Art Education and Preschool Education programs include more practical courses. The rate of cyberloafing was higher for male students in field-related courses and for female students in elective and vocational courses, and it was detected that male students had more problems with motivation. These results may be caused by differences in the satisfaction and expectations of male and female students from the programs they are enrolled in as well as related to their professional interests (subject matter knowledge, professional knowledge and general knowledge). The fact that cyberloafing is reported to be higher among more senior students may be related to the fact that such students think 
that they have background knowledge about their profession. In this regard, it might be recommended that instructors should pay attention to using motivating methods that make students active during the lesson; that they should establish multi-faceted communication with students; that they should focus on applied studies (micro-teaching, sharing internship experiences, discussing problems, designing syllabi, material development, etc.) especially during the last year's lessons and review the rules regarding the use of mobile phones in the lesson.

\section{Kaynakça / References}

Adıgüzel, A. (2008). Eğitim fakültelerinde öğretmen eğitimi program standartlarının gerçekleşme düzeyi. Yayımlanmamış doktora tezi. Anadolu Üniversitesi, Eğitim Bilimleri Enstitüsü, Eğitim Bilimleri Ana Bilim Dalı, Eskişehir.

Ahmad, A. and Omar, Z (2017). Understanding who cyberloafs from the selfcontrol perspective: A study in the public service sector. International Journal of Advanced and Applied Sciences, 4(8), 123-128.

Akbulut, Y., Dursun, Ö. Ö., Dönmez, O. ve Şahin, Y. L. (2016). In search of a measure to investigate cyberloafing in educational settings. Computers in Human Behavior, 55, 616-625.

Akdağ, S. (2014). Sosyal bilgiler öğrtemeni adaylarının öğretmenlik mesleğine yönelik tutumlarının bazı değişkenler açısından incelenmesi. Yayımlanmamış yükseklisans tezi. Atatürk Üniversitesi, Eğitim Bilimleri Enstitüsü, İlöğretim Ana Bilim Dalı, Erzurum.

Akgün, F. (2020). Investigation of high school students' cyberloafing behaviors in classes. Education and Science, 45 (201), 79-108.

Alshuaibi, A., Shamsudin, F. M. and Subramaniam, C. (2013). Do human resource management practices matter in reducing cyberloafing at work: Evidence from Jordan. Journal of WEI Business and Economics, 2(2), $1-11$.

Altay, D. ve Özerbaş, M. (2020). İlkokul öğrencilerinin problemli cep telefonu kullanımlarının farklı değişkenler açısından incelenmesi. TÜBAV Bilim Dergisi, 13(1) , 68-84.

Andreassen, C. S., Torheseim, T. and Pallesen, S. (2014). Predictors of use of social network sites at work- a specific type of cyberloafing. Journal of Computer-Mediated Communication, 19(2014), 906-921. 
Arabacı, İ. B. (2017). Investigation faculty of education students' cyberloafing behaviors in terms of various variables. The Turkish Online Journal of Educational Teknology, 16(1), 72-82.

Aykaç, N and Stebler, M. (2019). 2018 Türkçe öğretmenliği lisans programının öğretim elemanlarının görüşleri doğrultusunda değerlendirilmesi. Journal of Language Education and Research, 5(2), 116-138. DOI: 10.31464/jlere.610269

Bağrıaçık Yılmaz, A. (2017). Lisansüstü öğrencilerinin siber aylaklık düzeylerinin çeşitli değişkenler açısından incelenmesi: Karma bir çalışma. Ahi Evran Üniversitesi Kırşehir Ĕ̆itim Fakültesi Dergisi (KEFAD), 18(2), 113-134.

Baert, S., Vujić, S., Amez, S., Claeskens, M., Daman, T., Maeckelberghe, A. and De Marez, L. (2020). Smartphone use and academic performance: Correlation or causal relationship? Kyklos, 73(1), 22-46.

Blanchard, A. and Henle, C. (2008). Correlates of different forms of cyberloafing: The role of norms and external locus of control. Computers in Human Behavior, 24(3), 1067-1084.

Blau, G, Yang, Y. and Wark-Cook, K. (2006). Testing a measure of cyberloafing. Journal of Allied Health, 35, 9-17.

Brubaker, A. T. (2006). Faculty perceptions of the impact of student laptop use in a wireless internet environment on the classroom learning environment and teaching. Unpublished master thesis. School of Information and Library Science of the University of North Carolina University. North Carolina, USA.

Büyüköztürk, Ş. (2006). Sosyal bilimler için veri analizi el kitabı (6. Baskı). Ankara: Pegem A Yayincilik.

Caena, F. (2014).Teacher competence frameworks in Europe: Policy-asdiscourse and policy-as-practice. European Journal of Education, 49(3),311-331. https://doi.org/10.1111/ejed.12088

Candan, H. ve İnce, M. (2016). Siber kaytarma ve örgütsel bağlllık arasındaki ilişkinin incelenmesine yönelik emniyet çalışanları üzerine bir araştırma. Niğde Üniversitesi İktisadi ve İdari Bilimler Fakültesi Dergisi, 9(1), 229-235.

Cha, S. S. and Seo, B. K. (2018). Smartphone use and smartphone addiction in middle school students in Korea: Prevalence, social networking service, and game use. Health Psychology Open, January-June, 1-15. https://doi.org/10.1177/2055102918755046 
Chin-Hooi Soh, P., Koay, K. Y. and Lim, V. K. G. (2018). Understanding cyberloafing by students through the lens of an extended theory of planned behavior. First Monday, 23(6-4), 1-18.

Çınar, O. ve Cinisli, Z. (2018). Beden eğitimi ve spor öğretmenliği bölümü öğrencilerinin siber aylaklık davranışları. Beden Eğitimi ve Spor Araşttrmaları Dergisi (BESAD), 10(1), 39-48.

Çok, R. ve Kutlu, M. (2018). Üniversite öğrencilerin ders esnasında ders dışı internet kullanım davranışları ile akademik güdülenme düzeylerinin çeşitli değişkenlere göre incelenmesi. The Journal of International Lingual, Social and Educational Sciences, 4 (1), 1-21.

Dağtekin, A. ve Zorluoğlu, S. L. (2019). The opinions of academicians on the updated science education undergraduate program. SDU International Journal of Educational Studies, 6(1), 36-53. DOI: 10.33710/sduijes.538114

Demir, A. ve Ok, A. (1996) Orta Doğu Teknik Üniversitesindeki öğretim üye ve öğrencilerinin seçmeli dersler hakkındaki görüşleri. Hacettepe Üniversitesi Ĕ̆itim Fakültesi Dergisi, 12, 121-125.

Demir, A. (1996). Üniversitedeki seçmeli ders uygulamasının öğrenciler ve öğretim üyelerince değerlendirilmesi. Psikolojik Danışma ve Rehberlik Dergisi, 2(7), 24-31.

Demir, Ö. ve Seferoğlu, S. S. (2016). Bilgi okuryazarlığı, internet bağımlılığı, sanal aylaklık ve çeşitli diğer değişkenlerin sanal zorbalık ile ilişkisinin incelenmesi. Online Journal of Tecnology Addiction \& Cyberbullying, 3(1), $1-26$.

Dursun, Ö. Ö., Dönmez, O. ve Akbulut, Y. (2017). Öğrenci ve öğretim elemanı görüşleriyle siber aylaklık nedenleri. 11th International Computer $\mathcal{E}$ Instructional Technologies Symposium, Özet Kitabı, (s.55), $24-26$ Mayıs, 2017, Malatya.

Ergün, E. ve Altun, A. (2012). Öğrenci gözüyle siber aylaklık ve nedenleri. Eğitim Teknolojisi Kuram ve Uygulama, 2(1), 36-53.

Erişen, Y. ve Çeliköz, N. (2007). Ĕ̆itimde bilgisayar kullanımı. Öğretim teknolojileri ve materyal tasarımı. Ankara: Pegem A Yayınclik.

Flanigan, A. E. and Babchuk, W. A. (2015). Social media as academic quicksand: A phenomenological study of student experiences in and out of the classroom. Learning and Individual Differences, 44, 40-45. https://doi.org/10.1016/j.lindif.2015.11.003

Galluch, P. S. and Thatcher, J. P. (2007). Maladaptive vs. Adaptive use of internet applications in the classroom: A test of competing models. 
Paper presented at for Information Systems, 2007. International $\begin{array}{llll}\text { Conference on. } & \text { Retrieved } 2.02 .2019 & \text { from }\end{array}$ http://sais.aisnet.org/2007/SAIS07-07\%20Galluch-Thatcher.pdf

Genç, Z. ve Tozkoparan, S. B. (2017). Siber aylaklık nedenleri ölçeği: Bir ölçek geliştirme çalışması. Fırat Üniversitesi Sosyal Bilimler Dergisi, 27(1), 5361.

Gezgin, D. M. ve Çakır, Ö. (2016). Analysis of nomofobic behaviors of adolescents regarding various factors. Journal of Human Sciences, 13(2), 2504-2519.

Gezgin, D. M., Cakir O. ve Yildirim, S. (2018). The relationship between levels of nomophobia prevalence and internet addiction among high school students: The factors influencing Nomophobia. International Journal of Research in Education and Science (IJRES), 4(1), 215-225. DOI:10.21890/ijres.383153.

Giles, C. (2015). Undergraduate students' perceptions of cyberloafing. Retrieved from 20.04.2021 https://repository.tcu.edu/bitstream/handle/116099117/10333/Chase Giles Thesis Submission 15-05-03.pdf? sequence=1

Gökçe, F. ve Sezer, G. O. (2012). Öğretmen adaylarının öğretmenlik mesleğine yönelik tutumları (Uludağ Üniversitesi örneği). Eğitim Fakültesi Dergisi, 25(1), 1-23.

Gökdaş, İ., Torun, F. ve Bağrıaçık, A. (2014). Öğretmen adaylarının cep telefonlarını eğitsel amaçlı kullanım durumları ve mobil öğrenmeye ilişkin görüşleri. Adnan Menderes Üniversitesi Eğitim Fakültesi Eğitim Bilimleri Dergisi, 5(2), 43-61.

Guthrie, R. and Gray, P. (1996). Junk computing: Is it bad for an organization? Information Systems Management, 13(1), 23-28.

Gündoğar, D., Gül, S. S., Uskun, E., Demirci, S. ve Keçeci, D. (2007). Üniversite öğrencilerinde yaşam doyumunu yordayan etkenlerin incelenmesi. Klinik Psikiyatri Dergisi, 10(1), 14-27.

Hayıt, T. ve Dönmez, O. (2016). Üniversite öğrencilerinin siber aylaklık profilleriyle bilişsel kapılma düzeyleri arasındaki ilişkinin incelenmesi. Eğitim ve Öğretim Araștırmaları Dergisi, 5(16), 2146-9199.

Heflin, H., Shewmaker, J. and Nguyen, J. (2017). Impact of mobile technology on student attitudes, engagement, and learning. Computers and Education, 107, 91-99. https://doi.org/10.1016/j.compedu.2017.01.006 
Holguin, E. S. (2016). Strategies functional managers use to control cyberloafing behaviors. Unpublished doctoral dissertation. Walden University, USA.

Huma, Z., Hussain, S., Thurasamy, R. and Malik, M.I. (2017). Determinants of cyberloafing: A comparative study of a public and private sector organization. Internet Research, 27(1), 97-117.

İnce, M. ve Gül, H. (2011). The relation of cyber slacking behaviors with various organizational outputs: Example of Karamanoglu Mehmetbey University. European Journal of Scientific Research,52(4) , 507-527.

Jiang, F., Lin, S. and Mariano, J. M. (2016). The influence of Chinese college teachers' competence for purpose support on students' purpose development. Journal of Education for Teaching, 42(5), 565-581, DOI: 10.1080/02607476.2016.1226555

Kalaycı, E. (2010). Üniversite öğrencilerinin siber aylaklık davranışları ile öz düzenleme stratejileri arasındaki ilişkinin incelenmesi. Yayınlanmış Yüksek Lisans Tezi. Hacettepe Üniversitesi, Fen Bilimleri Enstitüsü, Bilgisayar ve Öğretim Teknolojileri Anabilim Dalı, Ankara.

Kaplan, M. ve Çetinkaya, A. Ş. (2014). Sanal kaytarma ve demografik özellikler açısından farklılıklar: Otel işletmelerinde bir araştırma. Anatolia: Turizm Araştırmaları Dergisi, 25(1), 26-34.

Kaplan, M. ve Öğüt, A. (2012). Algilanan örgütsel adalet ile sanal kaytarma arasındaki ilişkinin analizi: Hastane çalışanları örneği. İsletme Fakültesi Dergisi, 13(1), 1-13.

Karaca B. (2007). Ilköğretim ve ortaöğretim beden eğitimi öğretmenlerinin iş tatmini üzerine ampirik bir çalışma: Ankara'daki devlet ve özel okulların karşılaştırılması. Yayımlanmamış yüksek lisans tezi. Ankara Üniversitesi, Sağlık Bilimleri Enstitüsü, Ankara

Karaoğlan Yılmaz, F.G., Yılmaz, R., Öztürk, H. T., Sezer, B. ve Karademir, T. (2015). Cyberloafing as a barrier to the successful integration of information and communication technologies into teaching and learning environments. Computers in Human Behavior, 45, 290-298.

Karasar, N. (2012). Bilimsel araştırma yöntemleri (24. baskı). Ankara: Nobel Yayınevi.

Keklik, B., Kılıç, R., Yıldız, H. ve Yıldız, B. (2015). Sanal kaytarma davranışlarının örgütsel öğrenme kapasitesi üzerindeki etkisinin incelenmesi. Business and Economics Research Journal, 6(3), 129-144. 
Knight, R. (2017). Academic cyberloafing: A study of perceptual and behavioral differences on in-class cyberloafing among undergraduate students. Unpublished master's dissertation. East Carolina University, USA.

Koay, K. Y., Soh, P.C.H. and Chew, K.W. (2017). Antecedents and consequences of cyberloafing: Evidence from the Malaysian ICT industry. First Monday, 22(3-6), 1-16.

Kurt, M. (2011). Siber aylaklık davranışlarının karşılaştırmalı olarak incelenmesi. 5th International Computer \& Technology Symposium, Proceedings Book (Ed. Genç, Z. 22-24 September), Fırat Üniversitesi, s.935-941.

Kutanis, R. Ö., Karakiraz, A. ve Aras, M. (2014). İş stresi sanal kaytarma üzerinde etkili midir? 2. Örgütsel Davranış Kongresi, Sözlü bildiri, 7-8 Kasım, 2014, Kayseri.

Lamb, M. (2017). The motivational dimension of language teaching. Language Teaching, Surveys and Studies, 50(3), 301-346. doi:10.1017/S0261444817000088

Li, J., Lepp, A. and Barkley, J. E. (2015). Locus of control and cell phone use: Implications for sleep quality, academic performance, and subjective well-being. Computers in Human Behavior, 52, 450-457.

Lim, V.K.G. (2002). The it way of loafing on the job: Cyberloafing, neutralizing and organizational justice. Journal of Organizational Behavior, 23, 675694.

Odabaş, H. (2004). İnternet tabanlı uzaktan öğrenim modelinin bilgi hizmetlerine yönelik yükseköğretim programlarında kullanımı. Kütüphaneciliğin Destanı Uluslararası Sempozyumu, 21-24 October 2004, Ankara, Turkey.

Özcan, S., Gökçearslan, Ş. ve Yüksel, A. O. (2017). An investigation of the relationship between cyberloafing and academic motivation among university students. Ö. Demirel and S. Dinçer (Eds.), Trends in Distance Education: Theories \& Methods (s. 725-733). Ankara: Pegem A Yayıncllk.

Özgüngör, S. (2010). Eğitim fakültesi öğrencilerinin fakülte yaşantısına ilişkin doyum düzeylerine belirleyen öğrenci ve okul özellikleri. Türk Ĕ̆itim Bilimleri Dergisi, 8(3), 623-644.

Özkalp E., Aydın ve Tekeli S. (2012). Sapkın örgütsel davranışlar ve çalışma yaşamında yeni bir olgu: Sanal kaytarma (cyberloafing) ve iş ilişkilerine etkileri. Çimento İşveren Sendikası Dergisi, 26(2), 18-33. 
Sarhangpour, H., Baezzat F., and Akbari, A. (2018). Predicting cyberloafing through psychological needs with conscientiousness and being goaloriented as mediators among university students. International Journal of Psychology, 12(2), 147-168.

Slavin, R. E. (2013). Öğrencileri öğrenmeye motive etmek. G. Yüksel (Çev. Ed.), Eğitim Psikolojisi (s.284-312). Ankara: Nobel Akademik Yayıncllı.

Seçkin, Z. ve Kerse, G. (2017). Üniversite öğrencilerinin sanal kaytarma davranışları ve bu davranışların çeşitli değişkenler açısından incelenmesi: Ampirik bir araştırma. Aksaray Üniversitesi İktisadi ve İdari Bilimler Fakültesi Dergisi, 9(1), 89-110.

Serttaş, O. ve Şimşek, G. (2017). Konaklama işletmelerinde siber aylaklık: Çalışanların demografik özellikleri ile siber aylaklıkları üzerine bir araştırma. Uluslararası İktisadi ve İdari Bilimler Dergisi, Özel Sayı, 1, 2034.

Soh, P. C. H. and Yeik, K. K. (2018). Understanding cyberloafing by students through the lens of an extended theory of planned behavior. First Monday, 23(6/4), 1-18.

Solmaz, B., Tekin, G., Herzem, Z. and Demir, M. (2013). İnternet ve sosyal medya kullanımı üzerine bir uygulama. Selçuk İletişim, 7(4), 23-32.

Sürücü, A. ve Ünal, A. (2018). Öğrenci motivasyonunu artıran ve azaltan öğretmen davranışlarının incelenmesi. OPUS-Uluslararası Toplum Araştırmaları Dergisi, 8(14), 253-295. DOI: 10.26466/opus.404122

Şahan, H. H. ve Zöğ, H. (2017). An analysis of the relation between teacher candidates' attitudes toward the teaching profession and teachinglearning process competencies. Pegem Eğitim ve Öğretim Dergisi, 7(4), 583-610, http://dx.doi.org/10.14527/pegegog.2017.021

Şenel, S., Günaydın, S., Sarıtaş, M.T. ve Çiğdem, H. (2019). Üniversite öğrencilerinin siber aylaklık seviyelerini yordayan faktörler. Kastamonu Ĕ̆itim Dergisi, 27(1), 95-105.

Taneja, A., Fiore, V. and Fischer, B. (2015). Cyber-slacking in the classroom: Potential for digital distraction in the new age. Computers $\mathcal{E}$ Education, 82, 141-151.

Tezcan, H. ve Gümüş, Y. (2008). Üniversite öğrencilerinin seçmeli ders tercihlerine etki eden faktörlerin araştırılması. Gü. Gazi Eğitim Fakültesi Dergisi, 28(1), 1-17. 
Tindell, D. R. and Bohlander, R.W. (2012). The use and abuse of cell phones sand text messaging in the classroom: A survey of college students. CollegeTeaching, 60(1), 1-9.

Toker, S. ve Baturay, M. H. (2021). Factors afecting cyberloafng in computer laboratory teaching settings. International Journal of Educational Technology in Higher Education 18(20), 20-24.

Twum, R., Yarkwah, C. and Nkrumah, I. K. (2021). Utilisation of the internet for cyberloafing activities among university students. Journal of Digital Educational Technology, 1(1), 1-8. https://doi.org/10.21601/jdet/10912

Ugrin, J. C., Pearson, J. M. and Odom, M. D. (2008). Profiling cyber-slackers in the workplace: Demographic, cultural, and workplace factors. Journal of Internet Commerce, 6(3), 75 -89.

Ulukapı, H., Çelik, A. ve Yılmaz, A. (2014). Algılanan işe adanmışlığın sanal kaytarma davranışı üzerindeki etkisinin incelenmesi: Selçuk Üniversitesi örneği. 2. Örgütsel Davranış Kongresi, Sözlü bildiri, 7-8 Kasim, 2014, Kayseri.

Ülger, K. (2019). Yeni resim iş öğretmenliği lisans programının (2018) uygulamaya dayalı dersler açısından öğretmen adaylarının yaratıcı düşünme gelişimleri üzerine etkisinin incelenmesi. Bolu Abant İzet Baysal Üniversitesi Ĕ̆itim Fakültesi Dergisi, 19(4), 1561-1573.

Ünal, A. (2013). Teachers' deviant workplace behaviors: Scale development. Social Behavior and Personality: An International Journal, 41(4), 635-642.

Ünal, A. ve Gürsel, M. (2015). Negative teacher behaviors from which teacher candidates are affected. Proceedings of Teaching and Education Conferences (p.163-168). Amsterdam: International Institute of Social and Economic Sciences. doi: 10.20472/TEC.2015.001.013

Ünver, H. ve Koç, Z. (2017). Siber zorbalık ile problemli internet kullanımı ve riskli internet davranışı arasındaki ilişkinin incelenmesi. Türk Eğitim Bilimleri Dergisi, 15(2), 117-140.

Varol, F. ve Yıldırım, E. (2018). An examination of cyberloafing behaviors in classrooms from students' perspectives. Turkish Online Journal of Qualitative Inquiry (TOJQI), 9(1), 26-46.

Vural, Z. ve Bati, M, (2010). Yeni bir iletişim ortamı olarak sosyal medya: Ege üniversitesi iletişim fakültesine yönelik bir araştırma. Yaşar Üniversitesi Dergisi, 20(5), 3348-3382. 
Wu, J., Mei, W. ve Ugrin, J. C. (2018). Student cyberloafing in and out of the classroom in China and the relationship with student performance. Cyberpsychology, Behavior, and Social Networking, 21(3), 199-204.

Yaşar, S. (2013). Üniversite öğrencilerinin denetim odağı ve bilgisayar laboratuvarma yönelik tutumlarının siberaylaklık davranışlarına etkisi. Yayınlanmamış yüksek lisans tezi. Hacettepe Üniversitesi, Fen Bilimleri Enstitüsü, Bilgisayar ve Öğretim Teknolojileri Eğitimi Ana Bilim Dalı, Ankara.

Yıldırım, E. (2016). Sını öğretmenleri adaylarının siber aylaklık sorununa ilişkin durum analizi. Yayınlanmamış yüksek lisans tezi. Fırat Üniversitesi, Eğitim Bilimleri Enstitüsü, İlköğretim Ana Bilim Dalı, Elazı̆̆.

Yıldırım, A., Ünal, A. ve Sürücü, A. (2015). Effective teacher behaviors based on the opinions of teacher candidates. Proceedings of Teaching and Education Conferences (p.195-200). Amsterdam: International Institute of Social and Economic Sciences. doi: 10.20472/TEC.2015.001.017

Yıldız, H., Yıldız, B. ve Ateş, H. (2015). Sanal kaytarma davranışlarının sergilenmesinde örgütsel adalet algısının rolü var mıdır? Bilgi Ekonomisi ve Yönetimi Dergisi, 10(2), 55-66.

Yıldız, B. ve Yıldız, H. (2015). İş yaşamındaki sanal kaytarma davranışlarının hukuki yönden incelenmesi. Bandırma İ̈BF Yönetim ve Ekonomi Araştırmaları Dergisi, 13(3), 1-17.

Yıldız, H., Yıldız, B. ve İyigün, N. Ö. (2016). Psikolojik sözleşme algısının sanal kaytarma davranışları üzerindeki etkisi. Erciyes Üniversitesi İktisadi ve İdari Bilimler Fakültesi Dergisi, 47, 147-165.

YÖK. (2018). Öğretmen yetiştirme lisans programları. https://wwww.yok.gov.tr adresinden 3 Temmuz 2021 tarihinde alınmıştır.

Yurdakal, İ. H. (2018). Değişen sınıf öğretmenliği lisans program içeriğinin incelenmesi. Ulakbilge, 6(29), 1483-1499.

\section{Kaynakça Bilgisi / Citation Information}

Tatlı, Y. T. ve Sadık, F. (2021). Öğretmen adaylarının ders esnasında siber aylaklık yapma nedenlerinin incelenmesi. OPUS- Uluslararası Toplum Araştırmaları Dergisi, 18(43), 6530-6563. DOI: 10.26466/opus.933566. 